\title{
Does Race Have a Role in The Effect of Fingerprint on Gender?
}

\author{
Parmak İinin Cinsiyete Etkisinde Irkların Rolü Varmı?
}

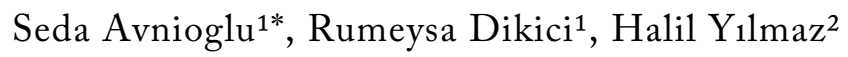

1.Alanya Alaaddin Keykubat University Faculty of Medicine, Department of Anatomy, Antalya, Turkey

2.Nersehir Haci Bektas Veli University, Kozakli Vocational School, Department of Therapy and Rehabilitation, Nersehir, Turkey

\section{ABSTRACT}

Aim: Fingerprint is one of the personal and reliable physical features. The fingerprint has an important role in forensics, and it is used in the detection of criminals and identity checks. Studies on different races have been conducted, but no interracial comparison has been found in the literature. In this study, we have investigated the effect of race on finger ridge using the same method on 5 different races.

Methods: In our study, the right thumb prints of 355 (148 female, 207 male) students aged 17-25 years in our school were taken with an ink pad (stamp) and recorded along with their ages, sexes, and races. Data were analysed by sex and race.

Results: In the comparison by sex, the finger ridge counts of male $(11.94 \pm 2.08)$ and female $(12.76 \pm 2.02)$ participants were found to be statistically significantly different $(p<0.001)$. Participants were classified as Turkish, Arab, Russian, Turkmen, and African. The difference in finger ridge counts between Turkish-Africans was found to be statistically significant in the comparison by races $(p<0.05)$.

Conclusion: Comparison of finger ridge counts by sex has been studied on many races, but each study has been conducted with a different method. In our study, we aimed to contribute to the literature by examining how the finger ridge counts of men and women differ in 5 different races by using the same method. Although the data we obtained are compatible with the literature for the Turkish race, there are differences for other races.

Keywords: Finger ridge density, Fingerprint, Sex determination, Turkish population

\section{Öz}

Giriş ve amaç: Parmak izi, kişiye özgü ve güvenilir fiziksel özelliklerdendir. Adl vakalarda önemli bir görevi olan parmak izi, suçluların tespiti ve kimlik denetiminde kullanımaktadır. Literatürde farklı ırklarda çalışmalar yapılmış; fakat ırklar arası bi karşılaşıımaya rastlanmamışır. Biz bu çalışma ile 5 farklı ırk üzerinde aynı metodu kullanarak parmak izi tepe noktasına ırk faktörünün etkisini belirlemeye çalıştık.

Method: Çalışmamızda, okulumuzun 17-25 yaş aralığındaki 355 (148 kadın, 207 erkek) öğrencinin sağ bașparmak izleri mürekkeple boyama yöntemi ile (Istampa) alınmış, yaş-cinsiyet ve ırkları sorgulanarak kaydedilmiştir. Her kişinin parmak izi tepe sayısı Bayes yöntemi (Acree) ile hesaplanmıştır. Veriler cinsiyet ve ırka göre analiz edilmiştir.

Bulgular: Cinsiyetlere göre karşılaştırmada erkeklerin baş parmak halka sayısı $(11.94 \pm 2.08)$ ve kadınların başparmak halka sayıları $(12.76 \pm 2.02)$ istatistiksel olarak anlamlı derecede farklı bulunmuştur $(p<0.001)$. Katılımcılar Türk, Arap, Rus, Türkmen ve Afrikalı olarak sınıflandırımıştır. Irklara göre karşılaştırmada Türk-Afrikalılar arasında parmak halka sayısındaki fark istatistiksel olarak anlamlı bulunmuştur $(p<0.05)$.

Sonuç: Sonuç olarak, birçok ırk üzerinde parmak izi tepe sayısının cinsiyetlere göre karşılaştırııması çalışılmış fakat her çalışma farklı metodla uygulanmıştı. Biz çalışmamızda 5 farklı ırkta kadın ve erkek cinsiyette tepe sayılarının nasıl değiştiğini aynı metodla inceleyerek literatüre katkı sağlamayı hedefledik. Elde ettiğimiz veriler Türk ırkı için literatür ile uyumlu olmakla beraber diğer ırklar için farklılıklar göstermektedir.

Anahtar Kelimeler: Parmak izi tepe yoğunluğu, Parmak izi, Cinsiyet belirleme, Türk popülasyonu

Received: 15.08.2021 Accepted: 26.08.2021 Published (Online): 30.08.2021

*Corresponding Author: Seda Avnioğlu, Alanya Alaaddin Keykubat University Faculty of Medicine,

Department of Anatomy, Antalya, Turkey.+902425106060, seda.avnioglu@alanya.edu.tr

ORCID: 0000-0003-1719-4190

To cited: Avnioğlu S, Dikici R, Yllmaz H. Does Race Have a Role in The Effect of Fingerprint on Gender? Acta Med. Alanya 2021;5(2):190-194 doi:10.30565/medalanya.983035 


\section{INTRODUCTION}

B iometric characteristics such as fingerprint, face, ear, iris, retina, hand geometry, voice, signature, and gait are physical characteristics that are unique enough to be different for each person and are too reliable to be passed on from family [1]. Fingerprint is a valuable identification tool with its uniqueness, immutability, and classifiable features. It is estimated that there is 1 in 64 billion chance that the fingerprints of any two randomly selected people will be the same [2]. It is possible to argue that the same fingerprint did not occur twice throughout the history of humanity [3].

Fingerprints are formed between 13th and 19th weeks of pregnancy. Fingerprints do not develop on the skin, they occur due to the protrusions in the flesh under the skin [4]. Genetic and racial factors play a role in the formation of fingerprints. There is a possibility that genetic problems during the formation of fingerprints may also change the structure of fingerprints [5]. In addition to genetic factors, the mother's diet, chemical intake, hormone levels, and environmental radiation can also have an effect in fingerprint pattern [6]. The position of the fetus in the womb and the density of the amniotic fluid also affect the formation of the fingerprint $[3,6]$.

Fingerprints have a very important role in forensic cases, and they are successfully used in many areas from detection of criminals to identity checks. They have started to be used not only in criminal identification, but also in access control, user's computer login, polling, and similar applications. Fingerprints are frequently used in identification, as fingerprints do not change even as people age [3].

Fingerprint image is the image obtained by scanning or taking a picture of the fingerprint. When we look at a fingerprint image with the naked eye, the protruding areas are represented with a colour close to black, and the recessed areas are represented with a colour close to white. The near-black protruding areas are called the "ridges," and the near-white recessed areas are called the "valleys" [4].

The fingerprint minutiae are distinctive in fingerprint analyses. Identification is carried out by using the fact that the distance between these points is different for each person. In studies examining the finger ridges, it has been argued that the finger ridge count differs by sex, and sex estimation can be made using this characteristic [5].

The Bayesian method, which Acree used in his study with 400 people in a police station in the USA in 1999, has been generally accepted, and this method started to be used. With this method, Acree showed that fingerprints with 11 ridges $/ 25 \mathrm{~mm} 2$ or less in a given area may belong to a male individual, and those with 12 ridges $/ 25 \mathrm{~mm} 2$ or more may belong to a female individual [6].

In the literature review on determining sex from fingerprints, it was concluded that women had more finger ridges than men. So, sex determination could be made from fingerprints [1, 6-8]. Studies on different races, although limited in number, have been conducted, but no interracial comparison has been found in the literature. In this study, we have investigated the effect of race on finger ridge using the same method on 5 different races.

\section{MATERIALS AND METHODS}

Our study started with the approval of Alanya Alaaddin Keykubat University Clinical Research Ethics Committee (Number: 2019:12-5). In our study, fingerprints of students at Alanya Alaaddin Keykubat University Faculty of Medicine and Dentistry Faculty and of foreign students at Turkish and Foreign Language Application and Research Center were used. The age, sex, and race information of the students between the ages of 17-25 years was inquired and recorded. The details of the study were explained in detail to each student, and an informed consent form was signed by the participants. Right thumb prints of the students were taken with an ink pad (stamp). This process was repeated three times, and the fingerprints were meticulously preserved.

In order to find the finger ridge count of each person, a method found by Acree was used. For this purpose, first of all, a square section of $5 \mathrm{~mm} \times 5 \mathrm{~mm}$ in the upper left part of the right thumbprint, starting from the core, was extracted from the fingerprint. The lower right corner of the 
square region taken from the right hand fingerprint sample shown in the figure is defined as the core point (Figure 1). The valleys and ridges in the 5 $\mathrm{mm} \times 5 \mathrm{~mm}$ region obtained from the upper left part of this point were calculated.

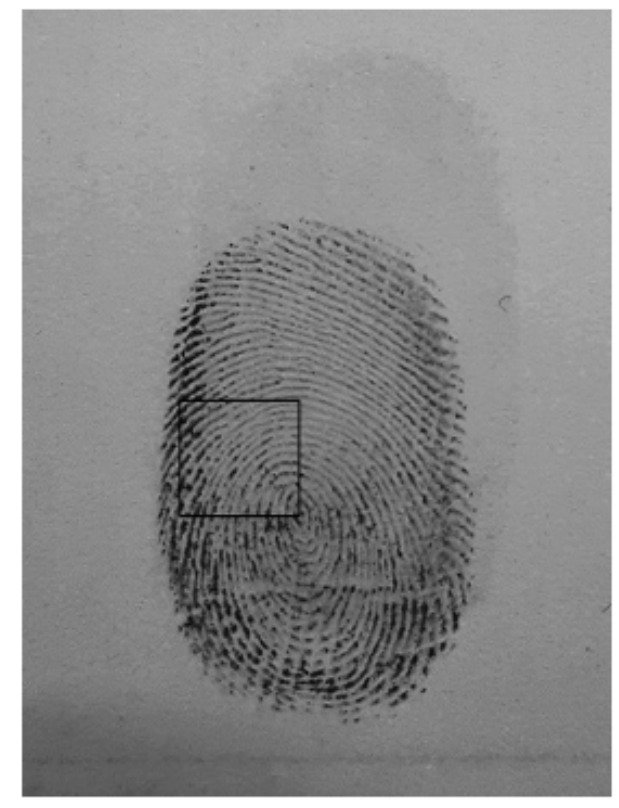

Figure 1: Core point and Bayerian Method

In the study, the sample size of 355 people who complied with the criteria determined as 1/1 sample also gives the sample size. Eighteen students were excluded from the research due to the predetermined criteria (absence of thumb, scarring, bandage due to temporary wounds, etc.). The demographic information (age, sex, nationality) of the participants in the study was recorded, and the loops on the thumb were counted. Data were analysed by sex and nationality.

Statistical analysis

In this study, the normal distribution was tested with skewness-kurtosis, histogram, Q-Q plots, standard deviation/mean, and KolmogorovSmirnov tests. Pearson correlation was used in the Independent Samples T-test correlation analysis in pairwise comparisons of normally distributed data. Kruskal-Wallis $\mathrm{H}$ test with Bonferroni correction was used in multiple comparisons of groups that were not normally distributed or had a small amount of data. In the statistical evaluation, $\alpha=0.05$ was accepted, and $p<\alpha$ was considered statistically significant. In this study, statistical analysis was carried out with IBM SPSS 22.00 package program.

\section{RESULTS}

Of the participants in the study, 148 men and 207 women. In the comparison by sex, the thumb fingerprint loop count was found to be $11.94 \pm 2.08$ for male participants, and it was found to be $12.76 \pm 2.02$ for female participants. This difference is statistically significant $(p<0.001)($ Table 1$)$.

Table 1: Comparison of the fingerprint loop count by sex

\begin{tabular}{|l|l|l|l|}
\hline Sex & N & $\begin{array}{l}\text { Mean Loop } \\
\text { Count }\end{array}$ & Sig.(p) \\
\hline Male & 148 & $11.94 \pm 2.08$ & \multirow{2}{*}{0.000} \\
\hline Female & 207 & $12.76 \pm 2.02^{* * * *}$ & \\
\hline
\end{tabular}

Independent Samples t-test $\left({ }^{*} \mathrm{p}<0.05,{ }^{* *} \mathrm{p} 0.01,{ }^{* * *} \mathrm{p} 0.001\right)$, Data are represented as mean \pm standard deviation, Variables are shown as Mean \pm STD.

***The difference in the fingerprint loop count between the sexes is statistically significant $\left({ }^{* * *} \mathrm{p}<0.001\right)$.

It is stated in the literature that the thumb fingerprint loop count is more than 12 for women and less than 12 for men. In order to test this information, frequency analysis between the sexes was carried out by making a cut-off value of 12 . In the ChiSquare analysis, there was a difference between the sexes according to the cut-off value $(p<0.05)$ (Table 2).

Table 2. Frequency Analysis by Sex

\begin{tabular}{|l|l|l|l|l|}
\hline Sex & $\begin{array}{l}\text { Loop count } \\
\text { below 12 }\end{array}$ & $\begin{array}{l}\text { Loop count } \\
\text { Above 12 }\end{array}$ & Total & Sig. (p) \\
\hline Male & 60 & 88 & 148 & Value: 4.29 \\
*Female & 62 & $145^{\mathrm{a}}$ & 20 & p:0.038 \\
\hline
\end{tabular}

Pearson Chi-Square test ( $\left.{ }^{*} \mathrm{p}<0.05,{ }^{* *} \mathrm{p} 0.01,{ }^{* * *} \mathrm{p} 0.001\right)$

a; The loop count of 12 or above is significantly higher in women than in men $(\mathrm{p}<0.05)$.

In our study, the demographic difference in the thumb fingerprint loop count was analysed by grouping the participants according to nationalities. Participants were classified as Turkish, Arab, Russian, Turkmen, and African. Due to the insufficient amount of data in some groups, the non-parametric Kruskal-Wallis $\mathrm{H}$ Test was used with Bonferroni correction in multi-group comparison. In the comparison by nationalities, the difference in the fingerprint loop count between Turkish-Africans was found to be statistically significant $(p<0.05)$. There was no 
significant difference between the other groups ( $p>0.05)$ (Table 3).

Table 3. Loop count analysis by nationality

\begin{tabular}{|l|l|l|}
\hline Nationality & N & $\begin{array}{l}\text { Mean Loop Count } \\
\text { Median (Min-Max) }\end{array}$ \\
\hline Turkish & 269 & $12(8-18)$ \\
\hline Arab & 41 & $13(9-17)$ \\
\hline Russian & 15 & $13(9-17)$ \\
\hline Turkmen & 16 & $13.5(9-17)$ \\
\hline *Africana & 14 & $14(11-16)$ \\
\hline
\end{tabular}

(Min: Minimum; Max: Maximum), Kruskal-Wallis $\mathrm{H}$ Test post hoc Bonferroni test $\left({ }^{*} \mathrm{p}<0.05,{ }^{* *} \mathrm{p} 0.01,{ }^{* * *} \mathrm{p} 0.001\right)$, Data are represented as Median (Min-Max), Variables are shown as Median (Min-Max)

a; The difference in the loop count between Africans and Turks is statistically significant $(\mathrm{p}<0.05)$

\section{DISCUSSION}

In order to distinguish fingerprints from each other, the fingerprint minutiae on each finger are examined. The frequency and arrangement of these fingerprint minutiae is different for each person. Since women have more detailed and specific fingerprints than men, when a certain area of the fingerprint is examined, it is seen that women have a higher ridge count than men. Accordingly, it can be stated that women's fingerprint images contain much more fingerprint minutiae [9]. Numerous studies have been conducted to examine the relationship between fingerprint and sex using these minutiae [10-14]. This information is used to save both time and energy in identifying the owner of the fingerprint by estimating their sex in legal cases and investigation processes [10].

According to the studies examining the relationship between fingerprint and sex in the literature, the average finger ridge count differs by sex and race, and the average finger ridge count of men is lower than that of women in any racial group [8, 10-17]. In our study, the average finger ridge count was found to be significantly different between sexes, the thumb fingerprint loop count was found to be $11.94 \pm 2.08$ for men and $12.76 \pm 2.02$ for women, and these values were found to be consistent with the findings in the literature.

In the study of Krishan K. et al., conducted with a total of 194 participants, 97 men and 97 women, aged between 18-25 years, a total of 1.940 fingerprints were taken, and the ridges in the epidermis in the upper left, upper right, and lower areas of these fingerprints were counted for each finger. Finger ridge densities were statistically compared by these three areas and by sex using t-test. The results showed that women have higher finger ridge density than men in all three areas. They reported that the finger ridge density in the upper right and upper left areas of the fingerprint had significantly higher values than the lower area [18].

In Acree's study on finger ridge on 100 AfricanAmerican women, 100 African-American men and 100 Caucasian women, 100 Caucasian men with criminal records, it is reported that if the ridge count is 11 ridges $/ 25 \mathrm{~mm} 2$ or below, the fingerprint is more likely to belong to a man, and if the ridge count is 12 ridges/25 mm2 or above, the fingerprint is more likely to belong to a woman [11].

Nayak et al.'s study on 200 people of Chinese origin (100 men and 100 women) and 100 people of Malaysian origin (50 men and 50 women) revealed that there were significant differences by sex in the finger ridge count. They reported that those with a finger ridge count of $12 / 25 \mathrm{~mm} 2$ or below were male, and those with a finger ridge count of $13 / 25 \mathrm{~mm} 2$ or above were female [12, $15]$.

Gutiérrez-Redomero et al. reported that the average finger ridge count in the population of 209 (99 male and 110 female) Caucasian Hispanic people was 17.91 in women and 16.23 in men [13]. Nithin et al. analysed fingerprints from 550 volunteers ( 275 male and 275 female) from the South Indian population, and reported that individuals with a finger ridge count of $13 / 25 \mathrm{~mm} 2$ or below were most likely male, and those with $14 / 25 \mathrm{~mm} 2$ or above were most likely female [14].

In the study conducted by Oktem et al. on the Turkish population, the average finger ridge count taken from 206 students (118 female-88 male) was found to be 14.52 in females and 12.92 in males [8].

Eshak G.A. et al. conducted a study with 752 participants from Egypt (380 male, 372 female) in which they examined ridge count, square area, finger breadth and finally ridge density through 
finger photographs, and reported that women had smaller finger breadth and square area but had more number of ridges and higher ridge density [19].

When the studies conducted around the world and the races used in these studies are considered, it is seen that the average finger ridge count of men is 12.68 ridges $/ 25 \mathrm{~mm} 2$, while the average finger ridge count of women is 14.88 ridges $/ 25 \mathrm{~mm} 2$. It is predicted that women have a higher finger ridge density than men. So, sex determination can be made using this characteristic. It has been seen that, in addition to the finger ridge density, the ratio of the ridge thickness to the valley thickness, the ridge count and the ridge width values can also be used in sex determination [10]. On the one hand, many studies in the literature are similar to our study, on the other hand, Mustanski et al. [20], Van Oel et al. [21], Ekanem et al. [22], and Wang et al. [23] reported higher finger ridge count in men than women.

As a result, the comparison of the finger ridge count by sex on many races has been studied, but not every study has used the same method. In this research we presented, we aimed to contribute to the literature with a different perspective by examining the differences in finger ridge count in women and men in 5 different races by the same researcher and the same method. Our study is a first in this respect. Although the results we obtained are compatible with the literature for the Turkish race, there are differences for other races.

In a conclusion; since our study is the first in this respect, it has some shortcomings. In particular, the inequality in the number of men and women and the low number of foreign racial fingerprints are among the limitations of our study. This study should be replicated with more people of a foreign race and by ensuring the same number of men and women.

Conflict of Interest: The author declares no conflict of interest related to this article.

Funding sources: The author declares that this study has received no financial support

Ethics Committee Approval: Alanya Alaaddin Keykubat University Clinical Research Ethics
Committee (Number: 2019:12-5).

Peer-review: Externally and internally peer reviewed.

\section{REFERENCES}

1. Eyüp Ceyhan , Ş.S., Emre Akyıl Parmak İi Öznitelik Vektörleri Kullanılarak Ysa Tabanlı Cinsiyet Sınıflandırma Gazi Üniversitesi Mühendislik Mimarlık Fakültesi Dergisi, 2014. 29(1): p. 201-207. https://doi.org/10.17341/gummfd.85657

2. Khadri, S.Y.G., E. S. ; Khadri, S. Y., A study of fingerprint pattern and gender distribution of fingerprint in and around Bijapur. Al Ameen Journal of Medical Sciences, 2013. 6(4): p. 328-31. ISSN 0974-1143

3. Chockaian, K., Vayanaperumal, R., \& Kanagaraj, B. R., New approach for identifying hereditary relation using primary fingerprint patterns. IET Image Processing, 2013. 7(5): p. 423-31. doi: 10.1049/iet-ipr.2012.0399

4. Sadi, M.S., et al., An Efficient Approach to Recognize Fingerprints. J. Multim., 2012. 7: p. 327-31. DOI:10.4304/jmm.7.5.327-331

5. Polat, M., Caner, M, Dermatoglyphic Signs In Patients With Colon Cancer. Ege Tıp Dergisi, 2000. 39(1): p. 39-44.

6. Gutierez, S.B., J.L.S. Lucenario, and M.J.T. Yebes, Dermatoglyphic Studies among the Dumagat-Remontado Tribal Population of the Philippines. Journal of Anthropology, 2012. 2012: p. 812128. doi:10.1155/2012/812128

7. Delice M, Duman A, Özel Ş.A, Parmak İzi Tipi Ile Suç Türü Arasındaki Ilişsininin İncelenmesi. Akademik Bakış Uluslararası Hakemli Sosyal Bilimler Dergisi, 2014. 43: p. 3-27.

8. Oktem, H., Kurkcuoglu A., Pelin I.C., Yazici A.C., Aktaş G., and Altunay F., Sex differences in fingerprint ridge density in a Turkish young adult population: a sample of Baskent University. J Forensic Leg. Med., 2015. 32: p. 34-38. PMID: 25882147

9. Moore, R.T., Automatic fingerprint identification systems. 1994, USA: CRC Press: Boca Raton. 164-91.

10. Ceyhan E.B., Sagıroglu Ș., Parmak izi ile cinsiyet arasındaki ilișki: Bir inceleme. Bartın Üniversitesi Mühendislik ve Teknoloji Bilimleri Dergisi, 2018. 6(1): p. 54-60.

11. Acree, M.A., Is there a gender difference in fingerprint ridge density? Forensic Sci Int, 1999. 102(1): p. 35-44. PMID: 10423851

12. Nayak, V.C.,Rastogi P, Kanchan T, Lobo S.W.,Yoganarasimha K., Nayak S., et al., Sex differences from fingerprint ridge density in the Indian population. J Forensic Leg Med, 2010. 17(2): p. 84-86. PMID: 20129427

13. Gutiérrez-Redomero, E. and C. Alonso-Rodríguez, Sexual and topological differences in palmprint and ridge density in the caucasian Spanish population. Forensic Sci Int, 2013. 229(1-3): p. 159.e151-110. PMID: 23601151

14. Nithin, M.D., Manjunatha B., Preethi D.S., Balaraj B.M. Gender differentiation by finger ridge count among South Indian population. J Forensic Leg Med, 2011. 18(2): p. 79-81. PMID: 21315302

15. Nayak, V.C., Rastogi P., Kanchan T., Yoganarasimha K., Kumar G.P., Menezes R.G. Sex differences from fingerprint ridge density in Chinese and Malaysian population. Forensic Sci Int, 2010. 197(1-3): p. 67-69. PMID: 20071110

16. Kaur, M. and K. Sharma, Dermal digital ridge density of a penal population: Analysis of association and individualization. J Forensic Leg Med, 2016. 44: p. 143-49. PMID: 27810584

17. Gungadin $\mathrm{S}$, Sex determination from fingerprint ridge density. Internet Journal of Medical Update, 2007. 2(2): p. 4-7. DOI: 10.4314/jijmu.v2i2.39847

18. Krishan, K., Kanchan, T., Ngangom, C. A study of sex differences in fingerprint ridge density in a North Indian young adult population. . J of Forensic and Leg. Med., 2013. 20(4): p. 217-22. PMID: 23622462

19. Eshak, G.A., Zaher J.F., Hasan E.I., Ewis A.A. Sex identification from fingertip features in Egyptian population. J Forensic Leg Med, 2013. 20(1): p. 46-50. PMID: 23217375

20. Mustanski, B.S., J.M. Bailey, and S. Kaspar, Dermatoglyphics, handedness, sex, and sexual orientation. Arch Sex Behav, 2002. 31(1): p. 113-22. PMID: 11910784

21. Oel Van C.J., Baare W.F., Pol Hulshoff H.E., Haag J., Balazs J., Dingemans A., et al. Differentiating between low and high susceptibility to schizophrenia in twins: the significance of dermatoglyphic indices in relation to other determinants of brain development. Schizophr Res, 2001. 52(3): p. 181-93. PMID: 11705712

22. Ekanem E.P., Eluwa M., Udoaffah G., Ekanem T. and Akpantah A. Digital Dermatoglyphic Patterns Of Annang Ethnic Group In Akwa Ibom State Of Nigeria. The Internet Journal of Biological Anthropology, 2008. 3.1 DOI:10.5580/2645

23. Wang J.F., Lin C.L., Chang Y.H., Nagurka M.L., Yen C.W. and Yeh C. Sex determination using fingertip features. Internet Journal of Medical Update. 3(2): p. 22-28. DOI: 10.4314/ijmu.v3i2.39838

\begin{tabular}{|l|l|}
\hline Author/ORCID & Authorship Contrubition \\
\hline $\begin{array}{l}\text { Seda Avnioğlu } \\
\text { 0000-0003-1719-4190 }\end{array}$ & $\begin{array}{l}\text { Consept, design, interpretation, literature search, } \\
\text { manuscript writing, final approval, critical review }\end{array}$ \\
\hline $\begin{array}{l}\text { Rumeysa Dikici } \\
\text { 0000-0003-3144-8740 }\end{array}$ & $\begin{array}{l}\text { Materials, data collection, literature review, } \\
\text { manuscript writing, final approval, critical review }\end{array}$ \\
\hline $\begin{array}{l}\text { Halil Yllmaz } \\
\text { 0000-0002-8234-4901 }\end{array}$ & Analysis, final approval, critical review \\
\hline
\end{tabular}

